\title{
Academic Tax Articles 1980-2000: Tax Faculty Productivity Analyses
}

Paul D. Hutchison, (Email: hutchp@unt.edu), University Of North Texas

Craig G. White, (Email: white@mgt.unm.edu), University Of New Mexico

\begin{abstract}
This study extends knowledge pertaining to accounting research productivity in taxation and provides data that may be useful for faculty career development or assessment purposes by administrators. The authors develop an academic tax article database that contains research from 1980 through 2000 and use it to review tax faculty publication quantity and timing over a 20-year career window for both those at doctoral and non-doctoral granting institutions. Results indicate that publication rates tend to spike within the first five years in academia for faculty at both doctoral and non-doctoral institutions and trail off from that point to year +20 . Further, faculty at doctoral schools published almost twice as many academic tax articles as faculty at non-doctoral institutions. Relative publication differences between faculty at the two school types remain constant over time. Additional insights include that non-tax accounting faculty contributed to almost half of all academic tax articles in the study, most faculty retain the tax designation during the first 20 years of their career, movement to doctoral schools by tax faculty happens early in a career, and in contrast, movement from doctoral schools happens later in academia.
\end{abstract}

\section{INTRODUCTION}

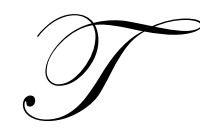

his research study examines accounting tax faculty and their academic tax article publication productivity from 1980 through 2000 by school type, doctoral and non-doctoral. It provides annual benchmarks over time for faculty career development and assessment purposes by administrators. It also examines movement by faculty to and from the tax teaching/research interest designation and doctoral schools. Therefore, the underlying objective of this study is to extend accounting knowledge pertaining to research productivity by faculty in an accounting subdiscipline, taxation.

Faculty are evaluated annually based on their performance in three areas: teaching, research, and service. Expectations for each segment vary by school and mission. Common goals are to ensure that faculty at the Assistant and Associate Professor levels are making adequate progress toward tenure and/or promotion, and those at the Full Professor level are maintaining expected standards. Measurement of success in the three performance areas is often difficult and based on varying and subjective criteria. Results from a study by Cargile and Bublitz (1986, 174) suggest that faculty perceive research is twice as important as teaching and five times more important than service in tenure and/or promotion decisions. Stone (1996, 188-189) found that tenure standards are increasing over time with more emphasis being placed on research. Additionally, most schools determine departmental standards for research based on their accreditation requirements that align with the strategic direction or mission of their department, college, and university (AACSB 2003a, 42; 2003b, 27). Thus, they will differ for accounting doctoral and non-doctoral granting institutions.

Since research productivity is important to accounting faculty, the need for benchmarks for career development and assessment purposes has led to academic research in this area. Previous accounting studies have examined productivity analysis by faculty over time from several different perspectives. Most utilized a "bottom-up" research method. ${ }^{1} \quad$ Illustrated by type of productivity study, these include: individual (Hasselback et al. 2001; Gopalkrishnan and Chandy 1991; Heck et al. 1991; Heck et al. 1990); institutional and accounting program (Hasselback and Reinstein 1995a; Posey and Parker 1989; Jacobs et al. 1986; Bublitz and Kee 1984); graduates of 
specific doctoral programs (Hasselback and Reinstein 1995b; Sriram and Gopalakrishnan 1994; Chung et al. 1992); faculty promotion (Englebrecht et al. 1994; Hagerman and Hagerman 1989; Campbell and Morgan 1987; Milne and Vent 1987); gender issues (Dwyer 1994; Streuly and Maranto 1994); and accounting subdisciplines (variousEnglebrecht et al. 1994; accounting information systems-Daigle and Arnold 2000; and tax- Kozub et al. 1990). Other lines of research based on productivity suggest norms for assessment and benchmarking (Christensen et al. 2002; Zivney et al. 1995; Cargile and Bublitz 1986).

Although there have been research studies that addressed aspects of the accounting subdiscipline of taxation (Englebrecht et al. 1994; Kozub et al. 1990), most have been limited by their methodological approach or inclusion of total publications, academic and professional articles. Therefore, this study extends previous literature by employing a "top-down" research method focusing on tax faculty and a subset of their publication records, academic tax articles. A "top down" approach has the advantages of efficiency and completeness. This method is not constrained by the researcher's ability to obtain individual faculty's vita. It includes all academics who publish tax articles in specific journals. This inquiry also presents data about tax publications by non-tax accounting academics, plus faculty movement between doctoral and non-doctoral schools and to and from the tax teaching/research interest designation.

The remainder of this article is organized in the following manner. First, a description of the development of the database used in this study is reviewed. This section is followed by an examination of publication productivity and related issues by tax and other accounting faculty. Finally, limitations, conclusions, and future research possibilities are identified.

\section{ACADEMIC TAX ARTICLE DATABASE}

This study utilizes a database of academic tax articles derived from manual and electronic reviews of various accounting-related journals. The initial group of periodicals identified is based on those used by Kozub et al. (1990) in their study that identified tax articles authored by business school faculty in the following academic journals: Advances in Taxation (AIT), Journal of Accounting and Economics (JAE), Journal of Accounting and Public Policy (JAPP), Journal of Accounting, Auditing \& Finance (JAAF), Journal of Accounting Research (JAR), National Tax Journal (NTJ), The Accounting Review (AR), and The Journal of the American Taxation Association (JATA). The list used in the current study is extended to include other American Accounting Association general journals, those with additional methodologies and perspectives, and other highly ranked accounting journals (Hasselback et al. 2001; Daigle and Arnold 2000; Brown and Huefner 1994). They are: Accounting Horizons (HOR), Accounting, Organizations and Society (AOS), Behavioral Research in Accounting (BRIA), Contemporary Accounting Research (CAR), and Issues in Accounting Education (IAE). This database also uses multiple issues of the Accounting Faculty Directory compiled by J. R. Hasselback (1980, 1981, 1982, 1983, 1984, 1985, 1987, 1988, 1989, 1990, 1991, 1992, $1993,1994,1995,1996,1997,1998,2000)$ published during this time period to allow for identification of accounting faculty and their demographic data. ${ }^{2}$

The time period selected for this study is 1980 through 2000. The beginning point of 1980 was chosen because it corresponds closely with the initial publication of JATA in 1979, the first academic accounting, tax-focused research outlet. The year 2000 was selected as the end point for consistency in the alignment of faculty career years, discussed in more detail below. Seven journals were present for all years (1980-2000) in the database (AOS, JAE, $J A A F, J A R, N T J, A R$, and JATA), while all 13 journals were published only from 1989-2000.

An examination of total articles by year graphically provides additional insights (see Figure 1). The graphic evidences that the quantity of tax articles has increased over time from 1980, primarily due to the introduction of additional publication outlets. The most articles produced was in 1989 with 53, while the least occurred in 1980 with 11 articles. From 1992 to the present, there have been approximately 40-50 academic tax articles published per year in these journals.

Overall, for the 13 academic journals identified in this study, approximately 831 journal editions and 6,636 articles were perused for inclusion in the Academic Tax Article Database. ${ }^{3}$ For all journals, except the National Tax Journal, the authors included all tax articles by all authors in the database, since these journals primarily publish 
studies by accounting faculty or are not devoted strictly to taxation. ${ }^{4}$ Due to the large number of tax articles published and since the focus of the present study is accounting faculty, the authors further restricted tax articles in the National Tax Journal to only those authored by accounting faculty as determined by Hasselback Accounting

Faculty Directory (1980-2000). Overall, there are a total of 715 separate tax articles identified for the years 1980 through 2000 in the Academic Tax Article Database and 662 different authors. ${ }^{5}$ Focusing specifically on accounting faculty, there are 552 members represented in the database ( 83 percent). They produced 650 weighted articles (91 percent). ${ }^{6}$

\section{FIGURE 1}

\section{Academic Tax Articles \\ By Database \\ 1980-2000}

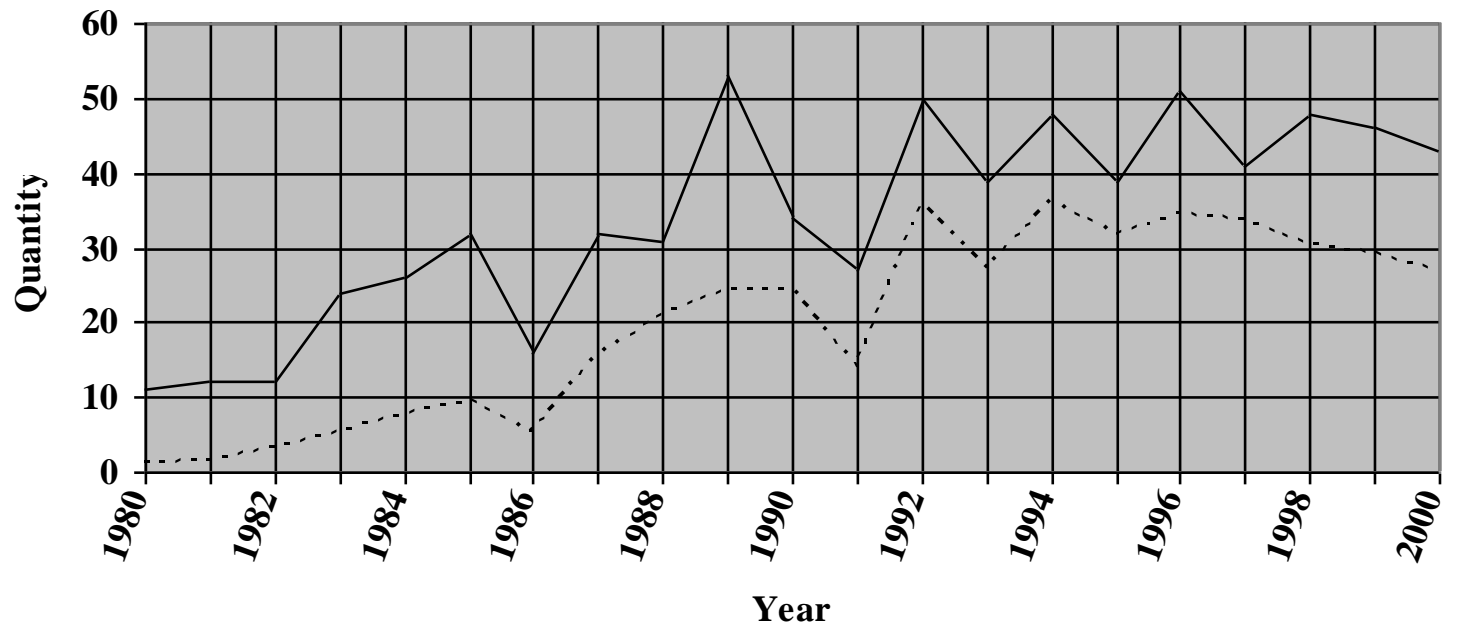

Full $\cdots \cdot \cdot$.... Reduced

\begin{tabular}{|c|c|c|c|c|c|c|c|c|c|c|c|}
\hline & 1980 & 1981 & 1982 & 1983 & 1984 & 1985 & 1986 & 1987 & 1988 & 1989 & 1990 \\
\hline Full & 11.00 & 12.00 & 12.00 & 24.00 & 26.00 & 32.00 & 16.00 & 32.00 & 31.00 & 53.00 & 34.00 \\
\hline Reduced & 1.00 & 1.50 & 3.00 & 5.17 & 7.50 & 9.50 & 5.33 & 15.33 & 20.83 & 24.33 & 24.13 \\
\hline & 1991 & 1992 & 1993 & 1994 & 1995 & 1996 & 1997 & 1998 & 1999 & 2000 & TOTALS \\
\hline Full & 27.00 & 50.00 & 39.00 & 48.00 & 39.00 & 51.00 & 41.00 & 48.00 & 46.00 & 43.00 & 715.00 \\
\hline Reduced & 13.83 & 35.58 & 27.00 & 36.00 & 31.50 & 34.50 & 33.67 & 30.33 & 29.00 & 26.83 & 414.88 \\
\hline
\end{tabular}

${ }^{a}$ Full $=$ Academic Tax Article Database with 662 total authors and Reduced = Accounting Faculty Database with 289 authors. Articles from the following academic journals are represented in these databases: Accounting Horizons; Accounting, Organizations and Society; Advances in Taxation; Behavioral Research in Accounting; Contemporary Accounting Research; Issues in Accounting Education; Journal of Accounting and Economics; Journal of Accounting and Public Policy; Journal of Accounting, Auditing \& Finance; Journal of Accounting Research; National Tax Journal; The Accounting Review; and The Journal of the American Taxation Association. Note: each article is weighted by the inverse of the number of authors for the Accounting Faculty Database. Due to initial publication, all 13 journals are present in the database from 1989-2000. 


\section{Accounting Faculty Database}

The authors reduced the Academic Tax Article Database to obtain a homogenous sample for this study that could be aligned in terms of individual author's career years. Further, this enables tracking the career timing of publications and demographics of tax research publishing accounting faculty. Table 1 presents details of the reduction.

\section{TABLE 1}

\section{Accounting Faculty Database 1980-1995}

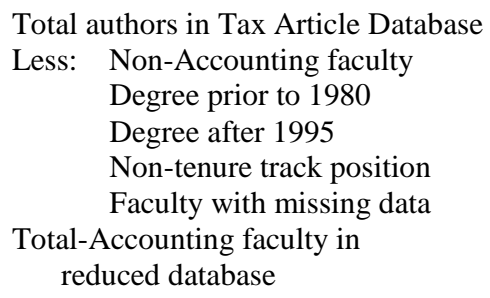

First, the 662-member author group of 715 tax articles is reduced by 110 non-accounting faculty authors. ${ }^{7}$ This reduction allows the study to focus only on accounting faculty who can be tracked through Hasselback Accounting Faculty Directory (1980-2000). Since publications are only included in the database starting in 1980, accounting graduates prior to 1980 may have tax publications that are not included in the database and ultimately bias the results of the study. Therefore, only graduates who received their degrees in 1980 or thereafter are included in the database. This results in the elimination of 182 authors. Another assumption made by the authors is that individuals seeking initial tenure and promotion do so upon completion of at least five years in academia. Thus, faculty who received terminal degrees after 1995 are removed from the sample to focus on the records of those faculty who meet the minimum number of years for tenure/promotion. This reduction results in the removal of 31 additional accounting faculty from the sample.

A few additional reductions were made to the database. A review of the remaining authors identified one as a lecturer. This individual was removed from the database under the assumption that this was not a traditional tenuretrack position. Also, since authors are categorized on a yearly basis, accounting faculty members must have appeared in every edition of Hasselback's Accounting Faculty Directory (1980-2000) from their year of graduation through 2000. Some individuals may leave academia for a period of time and not pursue publications for tenure and/or promotion. This constraint results in a further reduction of 49 accounting faculty members. Overall, the reduced Accounting Faculty Database contains a sample of 289 academics.

Figure 1 also shows the weighted quantity of tax articles by year for the Accounting Faculty Database. This database starts with only 11 faculty in 1980 and increases to 289 for 1995-2000, due to additional faculty being added each year by graduation date. The least amount of tax articles in this database are one weighted article in 1980, while the most was in 1994 with 36. This figure shows a somewhat similar pattern based on quantity over time as the Academic Tax Article Database. The biggest separation between the two databases occurs is in 1980 with only one article (9\%) from the full database to least separation in 1997 with 33.67 articles (82\%). 
FIGURE 2

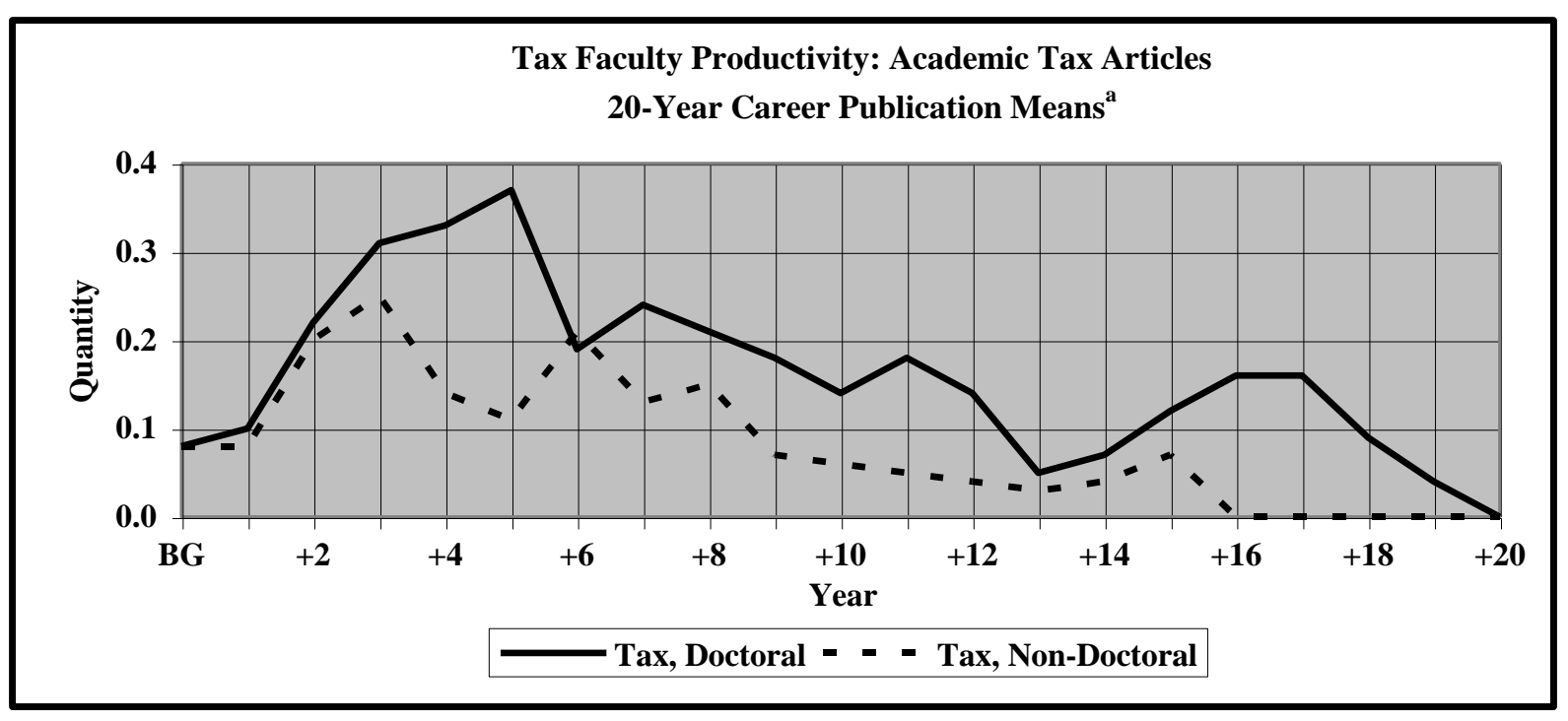

\begin{tabular}{|c|c|c|c|c|c|c|c|}
\hline \multirow[b]{2}{*}{ Year } & \multicolumn{2}{|c|}{ Publication Mean } & \multirow{2}{*}{$\begin{array}{c}\text { Quantity } \\
\text { Academic } \\
\text { Tax } \\
\text { Articles }\end{array}$} & \multicolumn{4}{|c|}{ Number of Faculty } \\
\hline & $\begin{array}{c}\text { Tax, } \\
\text { Doctoral }\end{array}$ & $\begin{array}{c}\text { Tax, } \\
\text { Non- } \\
\text { Doctoral }\end{array}$ & & $\begin{array}{c}\text { Tax, } \\
\text { Doctoral }\end{array}$ & $\begin{array}{c}\text { Tax, } \\
\text { Non- } \\
\text { Doctoral }\end{array}$ & $\begin{array}{c}\text { Other } \\
\text { Accounting }\end{array}$ & Total \\
\hline$\overline{B G}$ & 0.08 & 0.08 & 16.42 & 99 & 48 & 142 & 289 \\
\hline+1 & 0.10 & 0.08 & 19.92 & 99 & 48 & 142 & 289 \\
\hline+2 & 0.22 & 0.20 & 36.95 & 99 & 54 & 136 & 289 \\
\hline+3 & 0.31 & 0.25 & 50.17 & 100 & 54 & 135 & 289 \\
\hline+4 & 0.33 & 0.14 & 55.75 & 96 & 59 & 134 & 289 \\
\hline+5 & 0.37 & 0.11 & 54.12 & 96 & 59 & 134 & 289 \\
\hline+6 & 0.19 & 0.21 & 37.53 & 87 & 57 & 124 & 268 \\
\hline+7 & 0.24 & 0.13 & 32.25 & 73 & 59 & 120 & 252 \\
\hline+8 & 0.21 & 0.15 & 30.95 & 65 & 59 & 112 & 236 \\
\hline+9 & 0.18 & 0.07 & 20.58 & 58 & 56 & 105 & 219 \\
\hline+10 & 0.14 & 0.06 & 13.33 & 54 & 49 & 101 & 204 \\
\hline+11 & 0.18 & 0.05 & 12.58 & 45 & 45 & 88 & 178 \\
\hline+12 & 0.14 & 0.04 & 9.67 & 39 & 40 & 75 & 154 \\
\hline+13 & 0.05 & 0.03 & 3.50 & 32 & 35 & 68 & 135 \\
\hline+14 & 0.07 & 0.04 & 4.33 & 27 & 31 & 59 & 117 \\
\hline+15 & 0.12 & 0.07 & 6.50 & 23 & 25 & 49 & 97 \\
\hline+16 & 0.16 & 0.00 & 4.67 & 20 & 21 & 42 & 83 \\
\hline+17 & 0.16 & 0.00 & 3.33 & 19 & 12 & 32 & 63 \\
\hline+18 & 0.09 & 0.00 & 2.00 & 15 & 9 & 28 & 52 \\
\hline+19 & 0.04 & 0.00 & 0.33 & 8 & 7 & 14 & 29 \\
\hline+20 & 0.00 & 0.00 & 0.00 & 1 & 5 & 5 & 11 \\
\hline
\end{tabular}

${ }^{a}$ Tax, Doctoral refers to accounting faculty with a teaching/research interest in tax at accounting doctoral granting schools. Tax, NonDoctoral refers to accounting faculty with a teaching/research interest in tax at non-accounting doctoral granting schools. Other Accounting refers to non-tax accounting faculty. BG variable represents publications in year of graduation or prior.

The publishing record for each of the remaining 289 accounting authors in these journals is aligned by years since graduation (year $\mathrm{BG},+1,+2,+3$, etc.). All academic tax articles published prior to graduation are aggregated in the BG (before graduation) variable. For 1980 graduates, there are 20 career years available for examination, while at 
the other extreme, for 1995 graduates, there are five career years available for study. ${ }^{8}$ The number of articles published in the database journals is calculated for each individual for every year of the study. Similar to previous accounting research, the authors of the present study assume that each author contributed equally to the development of an article (Hasselback et al. 2001; Daigle and Arnold 2000; Kozub et al. 1990; Bublitz and Kee 1984). Therefore, each article is weighted based on authorship (Zivney et al. 1995). Finally, utilizing the Hasselback Accounting Faculty Directory for the years 1980 through 2000, each article author is categorized annually along two dimensions: tax designation or not, and employment at accounting doctoral or non-doctoral granting school. ${ }^{9,} 10$

\section{Publication Rates At Doctoral And Non-Doctoral Schools}

Using the Accounting Faculty Database, total sample size for the first five years after graduation holds at 289 faculty and then, begins to diminish to year +20 where it contains only 11 faculty (graduates from 1980). A graph of faculty publication rates shows points of both high and low activity.

Publication means were determined for BG and each year to +20 . The "Number of Faculty" portion of the data details faculty identifying themselves as accounting tax faculty at accounting doctoral granting institutions, accounting tax faculty at non-accounting doctoral granting institutions, and other accounting faculty who are not identified as tax. Obtaining this data by year entailed using Accounting Faculty Directory (1980-2000) by J. R. Hasselback to determine whether an author had a teaching/research interest in tax and if their employment school was an accounting doctoral granting institution from point of graduation year through 2000. The "Other Accounting" column represents non-tax accounting faculty that participated on one or more tax articles who met the database requirements.

Interestingly, in the early career alignment years $(\mathrm{BG}$ through year +3$)$, there are approximately twice as many tax faculty at doctoral institutions publishing in the database journals compared with tax faculty at non-doctoral schools. This difference tends to diminish in later career years until in year +12 when the number of non-doctoral school faculty surpasses the number of doctoral school faculty. This balance continues until year +17 when the number of doctoral school faculty publishing in these journals is again greater.

The overall publication rate (weighted publications) of tax accounting faculty members is similar in quantity at both doctoral and non-doctoral granting institutions in the early career years (BG to year +3 ). Tax accounting faculty initially employed by either doctoral or non-doctoral schools have .08 equivalent academic tax publications prior to graduation as noted by the BG variable. A closer examination of this variable shows that it represents 30 accounting faculty, approximately ten percent of all faculty in the reduced database. Further, publications occurred for 15 of the 30 while doctoral students at their degree university. This suggests that approximately five percent of the authors in the database participated in the publication of an academic tax article while a doctoral student and similarly another five percent of the authors published an article while in ABD (all but dissertation) status prior to tenure-track employment by a university.

\section{Tax Faculty At Doctoral Schools Productivity}

The annual publication rates for accounting faculty at accounting doctoral schools exhibit annual increases for years +1 to +5 . This group peaks at year +5 with .37 equivalent academic tax publications, the highest activity year out of the 20 years presented. Since research, preparation, submission, review, and acceptance of publications can be a lengthy process, the results suggest that tax faculty at doctoral schools actively seek academic publications in the first five years of their employment to meet school tenure and/or Associate Professor promotion requirements. The average publication rate then drops almost in half to .19 equivalent articles in year +6 . Most universities require that a decision on tenure and promotion be made during the sixth year of employment. ${ }^{11}$ These results are not unexpected since a tenure/promotion decision at doctoral institutions is generally based on research productivity in the first five career years. This group seems to consider publications in the sixth year to be less necessary.

The tax faculty at doctoral schools have an increase in publication rate in year +7 and then a sustained decrease in publication rates in years $+8,+9$, and +10 . They have a slight increase in publication in year +11 . This 
increase may represent publication efforts made to achieve promotion from Associate to Full Professor. ${ }^{12}$ After year +13 , the publication rate increases for a few years before going to zero for the remaining sample members in year +20 .

\section{Tax Faculty At Non-Doctoral Schools Productivity}

The publication rate pattern for tax accounting faculty at non-accounting doctoral granting institutions appears similar to, but one to two years ahead of that at doctoral granting schools. The publication rate for this group increases for the first three years (years +1 to +3 ) and then decreases for the next two years (years +4 and +5 ). Both the tax, doctoral and non-doctoral accounting faculty groups have similar publication rate increases in years +1 to +3 . One possible explanation for this pattern is that faculty at non-doctoral granting institutions reach academic journal publishing requirements for tenure and/or promotion sooner than those at doctoral granting institutions, or their decision for tenure and/or promotion to Associate Professor may occur earlier than the five year point. ${ }^{13}$ If indeed the academic journal publication requirement is lower at non-doctoral granting institutions, likely strategies during the final years before tenure consideration might include additional emphasis in the teaching and service areas and/or professional publications.

It is difficult to explain the spike in publications in year +6 for this group. It may reflect a final push for tenure and promotion or, as discussed further below, it may be a point at which tax faculty move from doctoral to nondoctoral granting universities. In this case, part of this productivity may evidence publications that were in process prior to their move to a non-doctoral school.

The years following year +6 exhibit a general decline in publication rates through year +13 . Similar to the explanation for the doctoral group, faculty have probably been considered for promotion to Full Professor by year +13 which may explain this low point. ${ }^{14}$ As with the tax, doctoral group, years +14 and +15 show small increases in publication rates. An explanation for this increase at this particular point of an academic career may be that tax faculty are co-authoring with junior faculty or students, or pursuing topics of personal interest. Noteworthy is the fact that the tax, non-doctoral accounting faculty group ceases all publication of academic tax articles after year +15 .

\section{Non-Tax Accounting Faculty Productivity}

This figure also provides insights about accounting faculty who do not elect to designate themselves as having a teaching/research interest in taxation, yet participate in the publication of tax articles. For the 1980 to 1995 graduates in the Accounting Faculty Database, academics without the tax designation contributed to the production of approximately 50 percent of all tax articles published in the 13 identified journals from 1980-2000. The low point occurred in year +20 with 45 percent, while the high point was year +18 with 54 percent of the publications by accounting faculty. These results suggest that accounting faculty who do not designate themselves as tax find value in publishing in these 13 academic journals.

\section{Cumulative Publication Data}

Figure 3 provides cumulative, weighted publication data by career year for tax accounting faculty at accounting doctoral and non-doctoral granting institutions. This information may be useful to identify benchmarks in terms of average academic publication performance for career development and assessment. Publication rates are similar for both groups up to year +3 . The gap between the two groups widens and reaches maximum separation at year +20 , the last year illustrated.

At the likely initial tenure and/or promotion to Associate Professor decision point, year +5 completed, the total academic tax publications for those at doctoral schools is 1.41 weighted articles in the 13 journals included in the database. The measure is 0.86 weighted articles for tax accounting faculty at non-doctoral schools. Therefore, the publication rate in the identified academic journals for tax faculty at doctoral schools is approximately 64 percent more than that for tax faculty at non-doctoral schools through year +5 . 
Assuming the decision point for Full Professor occurs by year +11 , the doctoral group has produced 2.55 weighted articles to 1.53 articles for the non-doctoral group. Again, the publication rate in these journals is approximately 67 percent more than for non-doctoral schools. This figure suggests that, although the absolute publication gap increases cumulatively over time, the difference in publication level at the promotion decision points is constant, 64 to 67 percent higher at doctoral granting schools. ${ }^{15}$

\section{FIGURE 3}

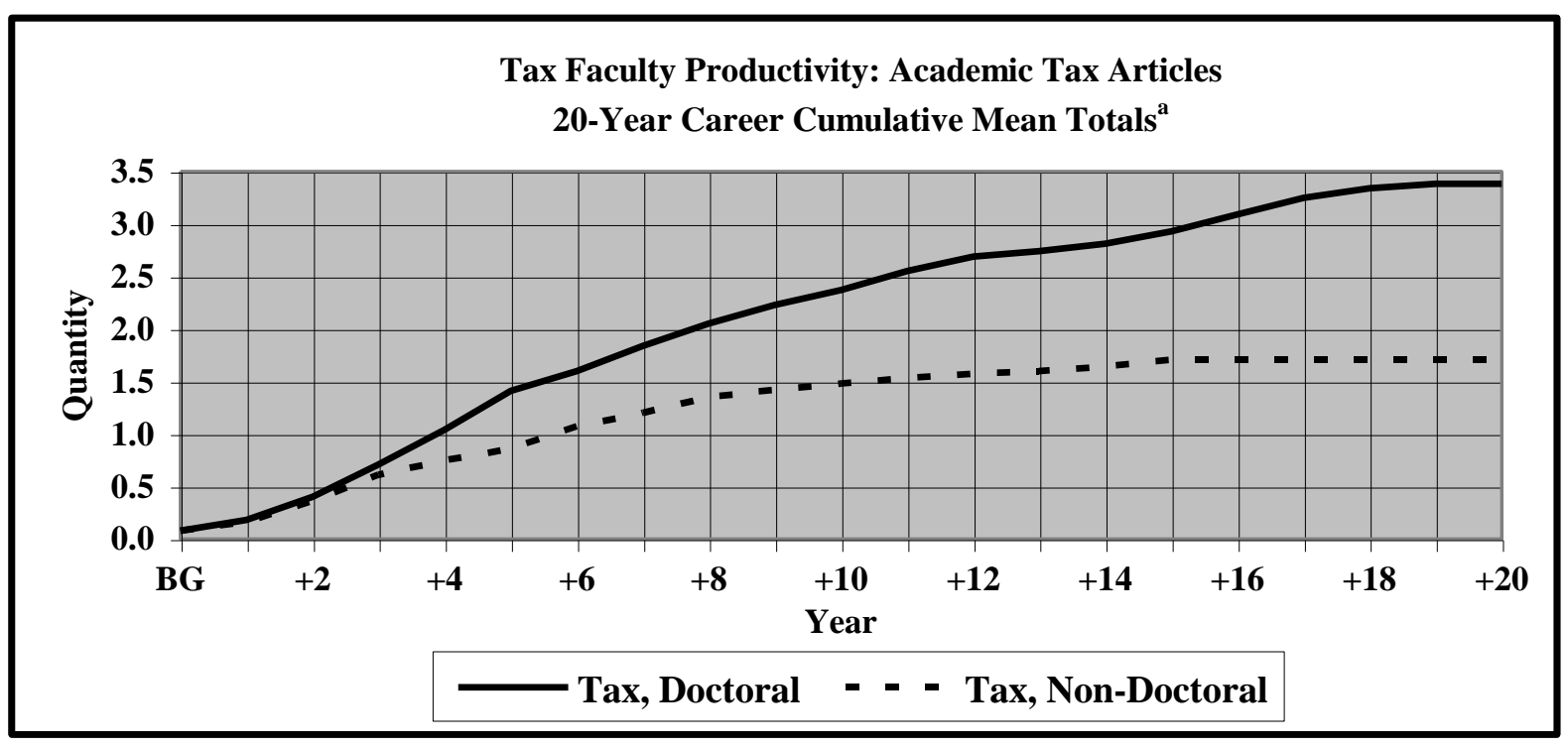

\begin{tabular}{|c|c|c|}
\hline \multirow{2}{*}{ Year } & \multicolumn{2}{|c|}{ Cumulative Mean Totals } \\
\cline { 2 - 3 } & $\begin{array}{c}\text { Tax, } \\
\text { Doctoral }\end{array}$ & $\begin{array}{c}\text { Tax, } \\
\text { Non-Doctoral }\end{array}$ \\
\hline BG & 0.08 & 0.08 \\
\hline+1 & 0.18 & 0.16 \\
\hline+2 & 0.40 & 0.36 \\
\hline+3 & 0.71 & 0.61 \\
\hline+4 & 1.04 & 0.75 \\
\hline+5 & 1.41 & 0.86 \\
\hline+6 & 1.60 & 1.07 \\
\hline+7 & 1.84 & 1.20 \\
\hline+8 & 2.05 & 1.35 \\
\hline+9 & 2.23 & 1.42 \\
\hline+10 & 2.37 & 1.48 \\
\hline+11 & 2.55 & 1.53 \\
\hline+12 & 2.69 & 1.57 \\
\hline+13 & 2.74 & 1.60 \\
\hline+14 & 2.81 & 1.64 \\
\hline+15 & 2.93 & 1.71 \\
\hline+16 & 3.09 & 1.71 \\
\hline+17 & 3.25 & 1.71 \\
\hline+18 & 3.34 & 1.71 \\
\hline+19 & 3.38 & 1.71 \\
\hline+20 & 3.38 & 1.71 \\
\hline
\end{tabular}

\footnotetext{
${ }^{a}$ Based on data from Figure 2. BG variable represents publications in year of graduation or prior.
} 
The cumulative total weighted publications are 3.38 academic tax articles in this database over 20 career years for tax accounting faculty at doctoral institutions. While 3.38 equivalent articles over a 20 -year time period may seem like a small quantity of academic tax publications by tax faculty, it represents minimum participation on at least four articles, e.g., three sole-authored and participation as a trio author on another tax article in the database. At the other extreme of authoring combinations, it could represent participation on approximately ten trio-authored works. Therefore, based on varying amounts of publication collaboration, productivity could range from a low of four to a high of ten academic tax articles during a 20-year academic career for tax faculty at an accounting doctoral institution.

For non-accounting doctoral schools, tax faculty produced 1.71 cumulative total weighted academic tax publications over the same 20 -year period. This could be obtained with two sole-authored works in the 13 journals or approximately five trio-authored articles. Again, given varying amounts of collaboration, participation could range from a low of two to a high of five academic tax articles for tax faculty over a 20 -year career at a non-doctoral institution.

\section{Cumulative Publications By Cohort Groups - Tax Faculty At Doctoral Schools}

The preceding analyses examined the trends in the overall sample. This portion of the study seeks to determine whether publication rates have shifted over time. Figure 4 details the 6-year cumulative publications for tax faculty members at accounting doctoral schools for graduates in 1980 through 1984, 1985 through 1989 , and 1990 through 1994 for years BG to year $+6 .^{16}$

FIGURE 4



\begin{tabular}{|c|c|c|c|c|c|c|}
\hline \multirow{2}{*}{ Year } & \multicolumn{6}{|c|}{ Cumulative Mean Totals } \\
\hline & 1980-84 & $\bar{n}$ & 1985-89 & $\mathbf{n}$ & 1990-94 & $\mathbf{n}$ \\
\hline $\mathrm{BG}$ & 0.10 & 29 & 0.02 & 34 & 0.14 & 30 \\
\hline+1 & 0.23 & 29 & 0.12 & 34 & 0.21 & 30 \\
\hline+2 & 0.42 & 30 & 0.40 & 32 & 0.38 & 30 \\
\hline+3 & 0.68 & 28 & 0.60 & 32 & 0.74 & 32 \\
\hline+4 & 0.96 & 27 & 0.87 & 32 & 1.16 & 29 \\
\hline+5 & 1.32 & 27 & 1.17 & 33 & 1.60 & 29 \\
\hline+6 & 1.48 & 26 & 1.38 & 33 & 1.81 & 28 \\
\hline
\end{tabular}

${ }^{a}$ Tax, Doctoral refers to accounting faculty with a teaching/research interest in tax at accounting doctoral granting schools. BG variable represents publications in year of graduation or prior. 
There are similarities across the groups. For instance, the graph of the cumulative means exhibits an inflection point at year +5 for each cohort. It suggests that the timing of publication pattern approaching tenure and/or promotion to Associate Professor decisions is similar across the period 1980 through 2000.

Additionally, Figure 4 exhibits some evidence of an increasing number of mean weighted publications leading up to tenure/promotion. The cumulative mean total for weighted articles is 1.48 for the 1980 through 1984 group, 1.38 for the 1985 through 1989 group, and 1.81 for the 1990 through 1994 group. This difference suggests participation on the equivalent of an additional trio-authored manuscript is required prior to tenure and promotion for the 1990 through 1994 group (22 percent increase) compared with the 1980 through 1984 group. However, a portion of this result may be attributable to the increasing number of tax articles in the 1990's relative to the 1980's due to additional publication outlets.

\section{Cumulative Publications By Cohort Groups - Tax Faculty At Non-Doctoral Schools}

Figure 5 details the 6-year cumulative publications for tax faculty members at non-accounting doctoral schools graduating in years 1980 through 1984, 1985 through 1989, and 1990 through 1994.

\section{FIGURE 5}

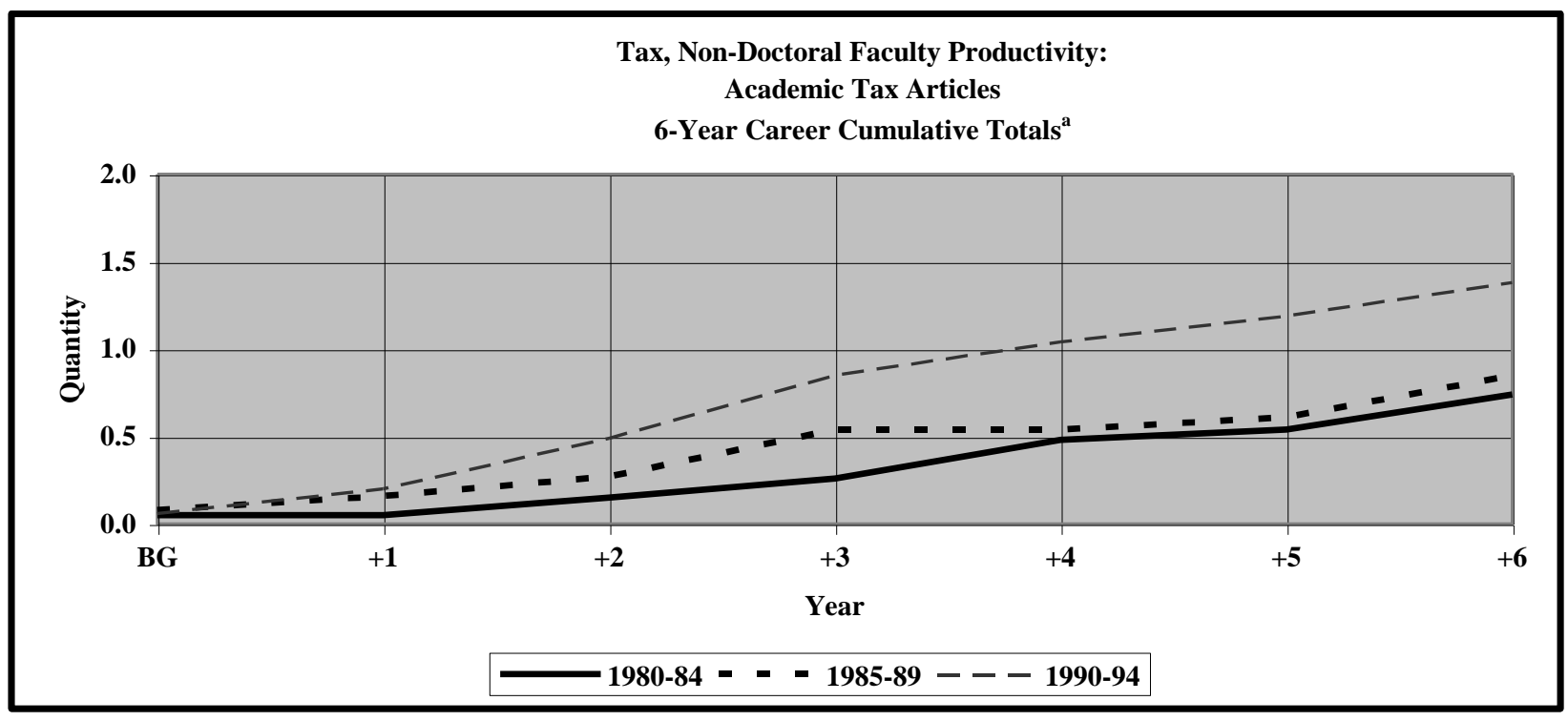

\begin{tabular}{|c|c|c|c|c|c|c|}
\hline \multirow{2}{*}{ Year } & \multicolumn{7}{|c|}{ Cumulative Mean Totals } \\
\cline { 2 - 7 } & $\mathbf{1 9 8 0 - 8 4}$ & $\mathbf{n}$ & $\mathbf{1 9 8 5 - 8 9}$ & $\mathbf{n}$ & $\mathbf{1 9 9 0 - 9 4}$ & $\mathbf{n}$ \\
\hline BG & 0.05 & 10 & 0.08 & 13 & 0.06 & 21 \\
\hline$+\mathbf{1}$ & 0.05 & 10 & 0.16 & 13 & 0.20 & 21 \\
\hline $\mathbf{+}$ & 0.15 & 10 & 0.27 & 16 & 0.49 & 24 \\
\hline$+\mathbf{3}$ & 0.26 & 12 & 0.54 & 16 & 0.85 & 22 \\
\hline$+\mathbf{4}$ & 0.48 & 13 & 0.54 & 17 & 1.04 & 25 \\
\hline$+\mathbf{5}$ & 0.54 & 13 & 0.61 & 17 & 1.19 & 24 \\
\hline$+\mathbf{6}$ & 0.74 & 15 & 0.85 & 18 & 1.38 & 24 \\
\hline
\end{tabular}

${ }^{a}$ Tax, Non-Doctoral refers to accounting faculty with a teaching/research interest in tax at non-accounting doctoral granting schools. BG variable represents publications in year of graduation or prior. 


\section{FIGURE 6}

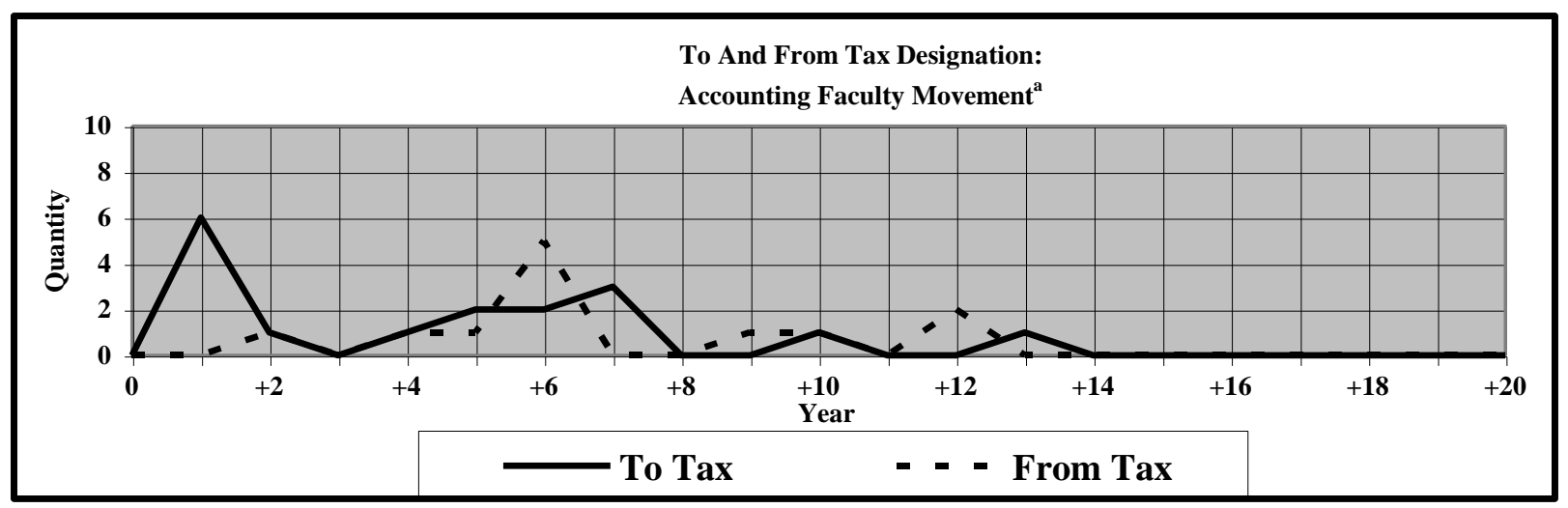

\begin{tabular}{|c|c|c|}
\hline \multirow{2}{*}{ Year } & To & Accounting Faculty \\
\cline { 2 - 3 } & Tax & $\begin{array}{c}\text { From } \\
\text { Tax }\end{array}$ \\
\hline+1 & 6 & 0 \\
\hline+2 & 1 & 0 \\
\hline+3 & 0 & 1 \\
\hline+4 & 1 & 5 \\
\hline+5 & 2 & 0 \\
\hline+6 & 2 & 0 \\
\hline+7 & 3 & 1 \\
\hline+8 & 0 & 1 \\
\hline+9 & 0 & 0 \\
\hline+10 & 1 & 2 \\
\hline+11 & 0 & 0 \\
\hline+12 & 0 & 0 \\
\hline+13 & 1 & 0 \\
\hline+14 & 0 & 0 \\
\hline+15 & 0 & 0 \\
\hline+16 & 0 & 0 \\
\hline+17 & 0 & 0 \\
\hline+18 & 0 & 0 \\
\hline+19 & 0 & 12 \\
\hline+20 & 0 & \\
\hline Total & 17 & \\
\hline
\end{tabular}

${ }^{a}$ Based on 289 accounting faculty.

This figure does not exhibit the same consistent inflection point trend as the doctoral school cohorts. For the 1980 group it occurs at year +4 , while the other two groups it occurs at year +3 . However, the graph does show an increase in the weighted number of publications in the database across cohort groups for the non-doctoral school tax faculty publishing in these 13 journals. The cumulative mean number of weighted articles is .74 for the 1980 through 1984 group, .85 for the 1985 through 1989 group, and 1.38 for the 1990 through 1994 group. Similar to the 1990 through 1994 doctoral school's cohort group, the increase in cumulative totals for the 1990 through 1994 group represents approximately the equivalent of an additional co-authored paper ( 86 percent increase) required by year +6 when compared with the 1980 through 1984 group. This increase may suggest that non-doctoral faculty are being encouraged to publish in these 13 journals, although not to the same extent as tax doctoral school faculty or again, the increase may simply be due to additional publication outlets. Interestingly, comparisons of these increases between 
tax, doctoral and non-doctoral schools shows that the non-doctoral schools have had a more substantive increase (approximately 400 percent: 86 percent vs. 22 percent) by comparison.

\section{Movement To And From Tax Designation}

The database affords the opportunity to explore the number of accounting faculty, publishing tax-related academic journal articles, that either change their teaching/research interest designation to Tax or drop the designation. Each of the 289 accounting faculty's specialty designations is identified from graduation year to 2000 using Hasselback's Accounting Faculty Directory (1980-2000). An individual was considered to be Tax if they had the taxation specialty interest designation by their name for that year, regardless of other interest designations. Although limited due to sample constraints, results are presented in Figure 6.

In the sample group of accounting faculty in the Accounting Faculty Database, 17 chose to add the Tax designation, while 12 elected to drop it. The overall implication of this figure is that the majority of accounting faculty stay with their initial teaching/research designation as Tax. Other observations can be made regarding the data below the figure in the table. Almost a third of those adding the Tax designation do so in the second year of listing in the Hasselback Accounting Faculty Directory. This finding is somewhat surprising due to a change so early in one's career. One explanation for this change may be that the designation was not correct the first year, and it was changed in the following year's edition of the directory. The largest occurrence of individuals dropping the tax designation occurs in year +6 of the sample. It appears this change may be related to issues surrounding the tenure and/or Associate Professor promotion decision.

An additional examination was made seeking to determine if individuals adding the Tax designation did so after publication of an academic tax article in one of the 13 journals in the database. Of the 17 individuals adding the Tax designation, six (35 percent) did so after publication of a database tax article.

\section{Movement To And From Accounting Doctoral Schools}

In order to examine the movement of the accounting faculty in the database, each of the 289 individuals was designated as at an accounting doctoral or non-doctoral school in their first year after graduation. Each author was then categorized for each year in the database as employed at a doctoral or non-doctoral school. Figure 7 provides the results of this analysis.

The figure indicates some clear patterns. The general movement, after initial employment, is from accounting doctoral granting to non-doctoral granting schools. In the database, there were 16 faculty moving to and 54 faculty moving from doctoral schools.

While the movement to doctoral schools by accounting faculty in the database is considerably smaller, the figure illustrates some unique points about this movement. Almost half of those identified move to doctoral schools in the first three years of their career. Additionally, 75 percent of the movement to doctoral schools occurs by the sixth year of employment (year +5$)$. Movement to doctoral schools after this time is very minimal.

The number of individuals moving from doctoral schools has two primary peaks, in year +3 and year +6 . This timing suggests that much of this movement is related to mid-tenure review (usually by year +3 ) and the tenure and/or promotion to Associate Professor decision (usually by year +6 ) points. The number moving from doctoral to non-doctoral schools remains relatively high in years +7 ( 6 faculty) and +8 ( 3 faculty). This may indicate that some take the achievement of tenure at a doctoral school as an opportunity to change their career focus and move to a nondoctoral institution.

Almost 65 percent of those making the change to a non-doctoral school do so by their seventh year (year +6$)$. The only other peak, although relatively small, occurs at year +13 . Again, this may indicate a move related to the promotion decision for Full Professor or perhaps a strong salary offer at a non-doctoral institution after promotion to Full Professor. 
FIGURE 7

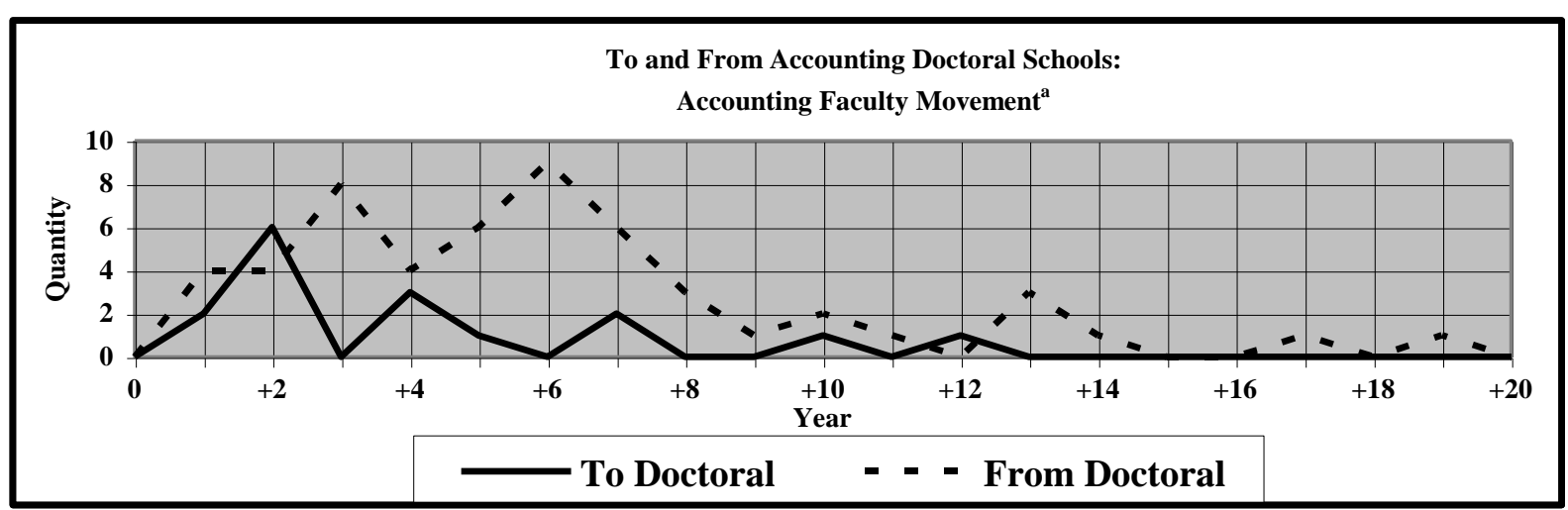

\begin{tabular}{|c|c|c|}
\hline \multirow{2}{*}{ Year } & Accounting Faculty & $\begin{array}{c}\text { From } \\
\text { Doctoral }\end{array}$ \\
\cline { 2 - 3 } & $\begin{array}{c}\text { To } \\
\text { Doctoral }\end{array}$ & 4 \\
\hline+1 & 2 & 4 \\
\hline+2 & 6 & 4 \\
\hline+3 & 0 & 6 \\
\hline+4 & 3 & 9 \\
\hline+5 & 1 & 6 \\
\hline+6 & 0 & 3 \\
\hline+7 & 2 & 1 \\
\hline+8 & 0 & 2 \\
\hline+9 & 0 & 1 \\
\hline+10 & 1 & 0 \\
\hline+11 & 0 & 3 \\
\hline+12 & 1 & 1 \\
\hline+13 & 0 & 0 \\
\hline+14 & 0 & 0 \\
\hline+15 & 0 & \\
\hline+16 & 0 & \\
\hline+17 & 0 & \\
\hline+18 & 0 & \\
\hline+19 & 0 & 1 \\
\hline+20 & 0 & 0 \\
\hline Total & 16 & \\
\hline
\end{tabular}

${ }^{\mathrm{a}}$ Based on 289 accounting faculty.

One possible explanation for faculty movement to and from doctoral institutions is a tax publication in one of the database journals spurs the move. This possibility was explored by the authors. Results indicate that five of the 16 accounting faculty (31 percent) moved to a doctoral school, while 14 accounting faculty (26 percent) moved to a non-doctoral school upon publication of an academic tax article in the database. This suggests that there is more of a propensity to move to than from a doctoral school upon publication of an academic tax article.

The above findings are consistent with anecdotal evidence. It is fairly rare for accounting faculty to move to a doctoral granting institution after initial employment at a non-doctoral school. Career changes are likely to occur at promotion and/or tenure decision points. 


\section{LIMITATIONS}

There are several limitations in this study due to the inherent constraints of the database. First, the research method employed takes a "top-down" approach by examining publication history in terms of individuals who have published academic tax articles. It does not build up from a listing of all accounting faculty identifying themselves with the tax designation. This method may weight the generalizability of the results towards faculty most likely to publish in academic journals. Another limiting factor is the construction of the Academic Tax Article Database (or the reduced Accounting Faculty Database). The list of journals used in creating the database is somewhat subjective and limited to academic tax publications. It does not consider other academic, professional, or educational articles by accounting faculty. Additionally, collection and classification of data by the authors is subjective. Quality and rigor of publication are also not considered in the analyses. The authors are further limited by the accuracy of the data presented in the Accounting Faculty Directory (1980-2000) by J. R. Hasselback. Finally, sample size may be a limitation. The alignment of publication by career years results in sample size reduction in the later years. The sample declines from 289 accounting faculty in year +1 to 11 faculty by year +20 , only 1980 graduates who were in the Hasselback Accounting Faculty Directory for all years 1980 through 2000.

\section{CONCLUSIONS}

The results of this study may correspond to most a priori expectations. However, what may be of interest to tax faculty is the timing and level of publication. The data suggest that the largest incentive to produce intellectual contributions is reaching tenure and/or promotion to Associate (or Full) Professor. The publication rate increases during the years after entering academia, peaks around the tenure and/ or promotion decision points, and then trails off over the later years. Although this data is limited to tax faculty and academic tax publications, it can be used for annual benchmarking by tax faculty interested in career development and for assessment purposes by administrators.

The analyses conducted in this study also suggest that the varying missions of doctoral and non-doctoral granting institutions directly impact the level of academic tax research and intellectual contributions by accounting faculty. Over a 20 -year career period, accounting doctoral school tax faculty publish almost twice as many academic tax articles as faculty at non-doctoral schools. Relative publication differences between the two school types remain constant over time. This amount may be understated due to the exclusion of tax faculty not included in the study's databases. Also, there is the likelihood that most non-doctoral granting school tax faculty have heavier teaching loads and variety of courses to teach and choose to focus exclusively on professional research.

Additional insights from this study include: 1) non-tax accounting faculty contributed to almost half of all academic tax articles, 2) most accounting faculty retain the tax designation over the first 20 years of their career, 3) some faculty add the tax designation upon publication of an academic tax article, 4) movement to doctoral schools by tax faculty happens early in a career (by the third year), 5) movement from doctoral schools happens significantly later in a career (by the seventh year), and 6) academic tax publications are more likely to spur movement to rather than from doctoral schools by tax faculty.

Overall, this research study evidences the timing of tax publications over a 20 -year academic career for tax faculty at doctoral and non-doctoral institutions. Insights gleaned from this inquiry contribute to the body of knowledge pertaining to accounting faculty research productivity and its subdiscipline, taxation.

\section{FUTURE RESEARCH}

As with any study and its analyses, there are several research inquiries that should be pursued. Tax faculty publication records contain academic, professional, and education articles. The present examination reviewed one aspect of academic articles, tax publications. A research study could be performed to determine other academic publications by tax faculty. Additionally, research could be directed at ascertaining publication of professional and education articles by tax accounting faculty. Annual data based from graduation date would be beneficial, and comparisons could be made to the present study. 
Additional productivity research could be directed at other accounting subdisciplines: financial, auditing, systems, managerial, etc. Similarly, productivity analyses over time could be performed based on Hasselback Accounting Faculty Directory teaching/research designations. Comparisons between this and other studies examining subdisciplines or designations could provide unique insights.

\section{ENDNOTES}

1. "Bottom-up" research approach involves initial identification of faculty and then their publication productivity, while a "top-down" approach involves initial identification of publications and then faculty.

2. A diligent effort was made by the authors to obtain all Hasselback Accounting Faculty Directory for 1980 through 2000. Unfortunately, they were not able to obtain one of the directories, 1986. Therefore, data for 1986 are extrapolated based on 1985 and 1987 directories.

3. This review included all categories in each of the identified journals except for the following: JAAF Views; $A R$ - Book Reviews and Committee Reports; JATA - Book Reviews, Committee Reports, Tax Software Reviews, and Doctoral Research; HOR - Comments and Reviews; CAR - Book Reviews; and IAE - Book Reviews. No publications from these categories are included in the tax article database.

4. The authors identified an article by title as tax if it contained the word "tax" or derivation thereof, or it dealt with a tax-related topic (e.g., charitable contributions, loss carryforwards, etc.

5. To enhance analyses, record entries for articles in the database are made separately by author. The tax article database contains 17 distinct fields for each record: journal name; title of article; author's first and last names; the journal edition's volume, number, season, year, and page number(s); category within the journal, if identified (i.e., Main Article, Notes, Education Research, Shorter Articles, Forum, etc.); designation of sole or multiple authorship; author's university at publication; author's university department and rank at publication, when available; and university where the author received their highest degree, the degree, and year of award. Each author of co-authored works is therefore listed separately. The 715 identified articles comprise a total of 1,303 separate record entries in the database due to multiple authorship.

6. Each article is weighted by the inverse of the number of authors (Zivney et al. 1995).

7. Authors are assumed to be accounting faculty if they appear in the Accounting Faculty Directory by J. R. Hasselback from 1980 to 2000. Examples of the group eliminated were faculty in other disciplines and accountants employed by accounting firms.

8. Hasselback does not delineate month of graduation (i.e., May-June, August, or December). Therefore, the $\mathrm{BG}$ variable contains all publications in year of graduation or prior.

9. Hasselback uses TAX, TX, or X in the Accounting Faculty Directory (1980-2000) to denote faculty with a teaching/research interest in Taxation.

10. Using "accounting faculty," rather than restricting the sample to only "tax faculty," allows the study to examine movement to and from the tax designation. It also provides some indication of tax article productivity by those who do not elect to designate themselves as tax.

11. Englebrecht et al. (1994) determined that promotion to Associate Professor occurred, on average, at 6 years, 1 month at doctoral granting schools.

12. Englebrecht et al. (1994) determined that promotion to Full Professor occurred, on average, at 11 years, 1 month at doctoral granting schools.

13. Englebrecht et al. (1994) determined that promotion to Associate Professor occurred, on average, at 5 years, 7 months at non-doctoral granting schools.

14. Englebrecht et al. (1994) determined that promotion to Full Professor occurred, on average, at 10 years, 11 months at non-doctoral granting schools.

15. Again, this gap reflects only tax faculty in the Accounting Faculty Database who actually published an academic tax article from 1980 to 2000 in one of the 13 academic journals. The gap would likely widen further between accounting doctoral and non-doctoral granting schools if all tax faculty, including those with graduation dates prior to 1980 and after 1995, were taken into account.

16. The underlying data reported under the graph provides the number of faculty members included in each mean calculation. 


\section{REFERENCES}

1. Association to Advance Collegiate Schools of Business. 2003a. Eligibility Procedures And Standards For Business Accreditation. St. Louis, MO: Association to Advance Collegiate Schools of Business, (April 25).

$2 . \quad$ 2003b. Second Working Draft; Eligibility Procedures And Standards For Accounting Accreditation. St. Louis, MO: Association to Advance Collegiate Schools of Business, (June 23).

3. Brown, L. D. and R. J. Huefner. 1994 . The Familiarity With And Perceived Quality Of Accounting Journals: Views Of Senior Accounting Faculty In Leading U.S. MBA Programs. Contemporary Accounting Research 11 (1-I) (Summer): 223-250.

4. Bublitz, B. and R. Kee. 1984. Measures Of Research Productivity. Issues In Accounting Education: 39-60.

5. Campbell, D. R. and R. G. Morgan. 1987. Publication Activity Of Promoted Accounting Faculty. Issues In Accounting Education 2 (1) (Spring): 28-43.

6. Cargile, B. R. and B. Bublitz. 1986. Factors Contributing To Published Research By Accounting Faculties. The Accounting Review 61 (1) (January): 158-178.

7. Christensen, A. L., C. A. Finger, and C. K. Latham. 2002. New Accounting Scholars Publications In Accounting And Nonaccounting Journals. Issues In Accounting Education 17 (3) (August): 233-251.

8. Chung, K. H., H. S. Pak, and R. A. K. Cox. 1992. Patterns Of Research Output In The Accounting Literature: A study Of Bibliometric Distributions. Abacus 28 (2):168-185.

9. Daigle, R. J. and V. Arnold. 2000. An Analysis Of The Research Productivity Of AIS Faculty. International Journal Of Accounting Information Systems 1 (2) (September): 106-122.

10. Dwyer, P. D. 1994. Gender Differences In The Scholarly Activities Of Accounting Academics: An Empirical Investigation. Issues In Accounting Education 9 (2) (Fall): 231-246.

11. Englebrecht, T. D., G. S. Iyer, and D. M. Patterson. 1994. An Empirical Investigation Of The Publication Productivity Of Promoted Accounting Faculty. Accounting Horizons 8 (1) (March): 45-68.

12. Gopalakrishnan, V. and P. R. Chandy. 1991. Most Frequent Contributors To Contemporary Accounting Literature. Akron Business And Economic Review 22 (3) (Fall): 97-107.

13, Hagerman, R. L. and C. M. Hagerman. 1989. Research Promotion Standards At Selected Accounting Programs. Issues In Accounting Education 4 (2) (Fall): 265-279.

14. Hasselback, J. R. 1980, 1981, 1982, 1983, 1984, 1985, 1987, 1988, 1989, 1990, 1991, 1992, 1993, 1994 , 1995, 1996, 1997, 1998, and 2000. Accounting Faculty Directory 1979-80, 1980-81, 1982, 1983, 1984, 1985, 1987, 1988, 1989, 1990, 1991, 1992, 1993, 1994, 1995, 1996, 1997, 1998-1999, and 2000-2001. Englewood Cliffs, NJ: Prentice-Hall, Inc.

15. and A. Reinstein. 1995a. A Proposal For Measuring Scholarly Productivity Of Accounting

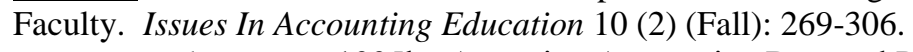

16. and 1995b. Assessing Accounting Doctoral Programs By Their Graduates' Research Productivity. Advances In Accounting 13: 61-86.

17. __ and E. S. Schwan. 2001. Prolific Authors Of Accounting Literature. Working Paper, presented at 2001 Annual Meeting of the American Accounting Association, Atlanta, Georgia.

18. Heck, J. L., R. E. Jensen, and P. L. Cooley. 1990. An Analysis Of Contributors To Accounting Journals; Part I: The Aggregate Performances. The International Journal Of Accounting 25 (3): 202-217.

19. , and 1991. An Analysis Of Contributors To Accounting Journals; Part II: The Individual Academic Accounting Journals. The International Journal Of Accounting 26 (1): 1-17.

20. Jacobs, F. A., A. L. Hartgraves, and L. H. Beard. 1986. Publication Productivity Of Doctoral Alumni: A Time-Adjusted Model. The Accounting Review 61 (1) (January): 179-187.

21. Kozub, R. M., D. L. Sanders, and W. A. Raabe. 1990. Measuring Tax Faculty Research Publication Records. The Journal Of The American Taxation Association 12 (1) (Fall): 94-101.

22. Milne, R. A. and G. A. Vent. 1987. Publication Productivity: A Comparison Of Accounting Faculty Members Promoted In 1981 And 1984. Issues In Accounting Education 2 (1) (Spring): 94-102.

23. Posey, R. B. and H. J. Parker. 1990. Publication Activity Of AACSB Accredited Accounting Programs. Accounting Educators' Journal (Summer): 32-38.

24. Sriram, R. S. and V. Gopalakrishnan. 1994. Ranking Of Doctoral Programs In Accounting: Productivity And Citational Analyses. Accounting Educators' Journal 6 (1): 32-53. 
25. Stone, D. N. 1996. Getting Tenure In Accounting: A Personal Account Of Learning To Dance With The Mountain. Issues In Accounting Education 11 (1) (Spring): 188-201.

26. Streuly, C. A. and C. L. Maranto. 1994. Accounting Faculty Research Productivity And Citations: Are There Gender Differences? Issues In Accounting Education 9 (2) (Fall): 247-258.

27. Zivney, T. L., W. J. Bertin, and T. A. Gavin. 1995. A Comprehensive Examination Of Accounting Faculty Publishing. Issues In Accounting Education 10 (1) (Spring): 1-25. 


\section{NOTES}

